\title{
EFL Teacher's Perception on Reading Strategies Taught in High Schools
}

\author{
${ }^{1 *}$ Dian Indrianis Fitri, ${ }^{2}$ Daniel Ginting \\ ${ }^{1}$ English Department, Faculty of Letters, Universitas Negeri Malang Jl. Semarang 5 Malang 65145, \\ Indonesia \\ 2English Literature Department, Faculty of Languages and Arts, Universitas Ma Chung, Villa Puncak \\ Tidar No. 01 Karangwidoro, Dau Malang 65151, Indonesia \\ *Corresponding Author e-mail: dianifkarim@gmail.com
}

Received: March 2021; Revised: June 2021; Published: July 2021

\begin{abstract}
While reading activity is a complex phenomenon, recent research on reading strategies has not provided comprehensive explanation of the role and perceptions of teachers regarding appropriate reading strategies helping students with learning difficulties. This paper is aimed to provide a sketch of the teacher's views and strategies to facilitate students with appropriate reading strategies. EFL teachers have different kinds of reading strategies applied in the classrooms. This study has found that three groups of teachers teaching in excellent accredited public schools, good accredited public school and very good Islamic private school use various strategies during the teaching of reading. Teachers' perceptions on the teaching of reading strategies are closely related to their readiness with knowledge about reading strategies, students' reading problems and their belief. This study suggests that EFL teachers and future researchers need to continuously investigate effective teaching of reading skill in relation to students' reading strategies.
\end{abstract}

Keywords: EFL teacher's perception; reading strategies

How to Cite: Fitri, D. I., \& Ginting, D. (2021). EFL Teacher's Perception on Reading Strategies Taught in High Schools. Jurnal Penelitian dan Pengkajian Ilmu Pendidikan: e-Saintika, 5(2), 104-117. https://doi.org/10.36312/esaintika.v5i2.423

https:// doi.org/10.36312/esaintika.v5i2.423

Copyright $\odot$ 2021, Fitri \& Ginting This is an open-access article under the CC-BY-SA License.

\section{INTRODUCTION}

The nature of reading is a challenging process. In the reading process, students are challenged to identify words in print, construct the meanings of the text and coordinate identifying words and making meaning so that the students achieve their reading fluency. Troike (2012) has mentioned that the following functions for reading in academic settings are likely to create difficulties for L2 learners such as reading to find information, reading for general understanding, reading to learn and reading to critique and evaluate. Dogan and Tosun (2019) have mentioned some difficulties in the reading process such as to understand the general meaning of a text, to make inferences about the intention of the text, to detect the supporting ideas of the text, etc.

Teachers play important roles to help students cope with reading challenges. For example, they can provide good reading materials, sources or specific techniques and preparation. During the class, EFL teachers are also demanded to show their professionality in managing the class, in accelerating students' comprehension about 
texts and also in delivering the instructions. Emaliana (2008) mentions that teachers have responsibilities to lead the class activities in order to guarantee the success of classroom teaching. Dubin and Bycina mention that EFL teachers should avoid simply asking the learners to answer the questions following a reading text. This activity is more like a testing rather than teaching strategy; as a result, such an approach does not engage students in the improvement of reading skills and strategies. Fitri (2011) says that English teachers need to help students with reading strategies in the classroom. Students will get much benefit in future life when they are taught to apply comprehension strategies when they read (Herman et. al, 2010). It is important for students in high schools to understand what they got from teachers not merely just follow the instruction for better learning result and continuity of their reading development. Nugroho (2019) states a teacher should have good perception of teaching and strategies to deal with some difficulties that can be aroused in the process of reading. That is why, it is important to know EFL teachers' perception on reading strategies that have a considerably positive effect on practices/ activities.

Recent developments in teachers' perceptions have shed on the need for motivating students more on content of a passage, some tenses and patterns in a short paragraph. Teachers' perception may impair the reading process experienced by students. EFL teachers should push their ability in modelling or facilitating the English classroom by reading strategies as well as enhance enjoyable learning. As stated by Vasquez (2010), by considering the characteristics of effective readers, EFL teachers can teach explicit reading strategies to the EFL learners, give the tools to become more aware of developing their reading skills. To develop new conceptual understanding about reading strategy practiced, students should understand words as much as they can translate those vocabularies as well as teachers should activate learners' previous knowledge about the topic to help them understand the learning process physically, mentally and emotionally. The use of appropriate strategies may improve reading comprehension. Hudri \& Naim (2019) state that teachers can apply three strategies in teaching reading: memorizing strategy where students must memorize five vocabularies every meeting, question answer relationship to know the students understand or not and game strategy to motivate students in teaching reading process. Moreover, students should be equipped with some strategies in reading to fasten their understanding about the process had happened, related to the context of promoting their critical reading ability.

Strategies are specific methods of approaching a problem or task, modes of operation for achieving a particular end, planned designs for controlling and manipulating certain information (Brown, 2007). In this case, Zhang (1993) recommended that reading strategies that have been identified by recent literature can be classified into four categories: cognitive, compensation, memory and test-taking strategies as direct strategies for reading comprehension. Using reading strategies can be of great help to non-native readers because it may serve as an effective way of overcoming language deficiency and obtaining better reading achievement both for regular school assignments and on language proficiency tests. Djiwandono (1994) said that metacognitive strategy is one of indirect reading strategies beside affective strategies which help to regulate and control emotions, motivations, attitudes and social strategies which involve interacting with another person or learning aid to assist comprehension. 
Cahyono and Widiati (2006) states that ESL/ EFL reading teachers should not overlook the need for students to work on language, but at the same time the language should not overshadow reading. They should also attempt to train students to become efficient, effective and independent readers. Brevik (2019) stated that key findings show that teachers engage their students in reading comprehension instruction of narrative and expository texts more than half the time, offering guided strategy practice based on student needs, and encouraging daily use of known reading comprehension strategies, instead of explicitly teaching new ones. That is why a teacher is seen to pay much concerns and expectations into adolescent literacy as the need to handle a plenty of texts across content subjects as well as to help English language learners to grow up and solve their reading problems. Teachers should be aware of the reading strategies that their students use (Ali \& Razali, 2019). Using some well-established inventories of reading strategies, they should introduce their students to useful reading strategies which would increase their comprehension when reading English academic materials. This is indeed a need if a teacher can surely show the strategy provided, students will be able to learn strategy precisely

In addition, Mahmoed (2019) said that a very important aspect should be emphasized in teaching reading to high-school students is guiding students on how to independently choose and effectively use reading strategies to comprehend different reading texts. Building reading habits will better help students to improve reading skills, and consequently, improve all other English relative aspects. They show that high-school teachers use various reading strategies to teach reading. Hidayati (2018) has mentioned factors that hinder students' reading comprehension such as main idea, detail information, making inferences, locating reference, and vocabulary. Some other difficulties include answering main idea, making inference, and locating reference questions, finding main idea questions, because the located main idea was difficult to find, in understanding vocabulary, poor mastery of grammar, the difficulty in understanding long sentences, lack of media learning, less support from the family, lack of knowledge of strategies in reading comprehension. It is undeniable that cognitive and metacognitive strategies are challenging to be used as ESL/EFL students still face different kinds of difficulties in their learning of reading comprehension (Ali \& Razali, 2019). Moreover, Cahyono and Widiati (2006) says the need of the learners to be skilled in reading to learn has inspired EFL reading teachers or specialists to apply some techniques in the teaching of EFL reading and to investigate the effects of the techniques on improving Indonesian students reading skills, as well as to examine various related aspects such as reading materials, reading strategies, and factors affecting reading comprehension. Teaching relevant reading strategies certainly benefit students. With relevant strategies, they are expected to be able to complete class assignments and their daily lives, including the challenges they will face during school exams that determine their graduation from school (Ginting \& Saukah, 2016).

While reading activity is a complex phenomenon, recent research on reading strategies has not provided a comprehensive explanation of the role and perceptions of teachers regarding appropriate reading strategies for assisting students with learning difficulties. Furthermore, numerous studies on the reading process have been conducted and found the review of EFL literature, the topic of reading strategies related to teachers' perceptions has not been studied and discussed intensively. This paper is aimed to provide a complete picture of the teacher's views and strategies to 
facilitate students with appropriate reading strategies, and shed on the EFL teachers' perceptions on kinds and terms of reading strategies taught to high school students. Two research questions are presented as follows: how EFL teachers' perception about reading strategies they taught? Do EFL teachers know kinds of reading strategies to help their students dealing with texts?

\section{METHOD}

The design of this present study is descriptive qualitative study (see Figure 1) which aims to identify and figure out the teachers' perceptions on reading strategies. Prior the observation, the writers consulted the headmaster and asked for the permission. Having got the permission, the researchers discussed the observation schedules with the teachers. Observations were held two times during the English classes to take notes in actual practice of reading class. The researcher came to do observation to each school. The researchers were filling out the observation checklist while observing the teachers teaching their reading classes.

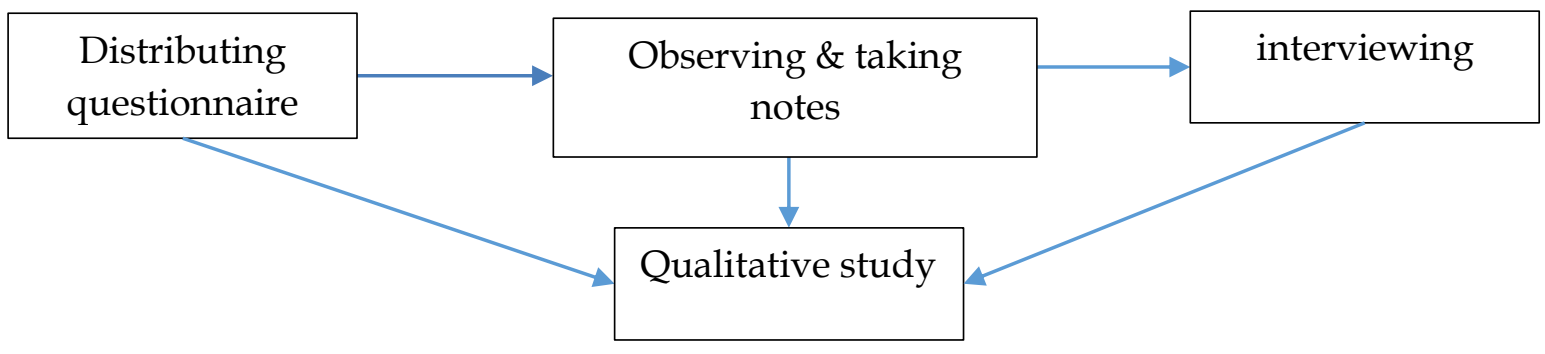

Figure 1. Research Design

The participants were six EFL high school teachers who had different teaching experiences in junior high schools located in Malang regency. As subject of this study, two EFL teachers represented junior high school teachers from good accredited public schools, three EFL teachers were from excellent accredited public schools and the other was from very good accredited private Islamic school. They were observed and interviewed during their regular reading classes in one semester. After the observation, the researcher took some notes with them. These teachers shared their views, thoughts and opinions about real practice, their thoughts and hopes during the teaching and learning process in reading class. We intentionally use pseudo names for our subject of the study for ethical consideration. For example, A and B refer to two EFL teachers teaching at good accredited public junior high school, C, D and F refer to those teaching at excellent accredited public schools. Meanwhile, D is a teacher teaching at very good accredited private Islamic school.

The researchers made use of several techniques for data gathering such as interview guide, questionnaire, observation checklist and field notes. To answer the research questions, the questionnaire that consists of 21 items have been developed by adopting Hudson's (2021).

According to Nugroho (2019), after collecting the data, the writer analyzed the data in some steps as follows: (1) identified the teachers' responses, (2) classified the responses, the difficulties and the strategies into the teachers' perceptions, (3) analyzed the perceptions, the difficulties, and the strategies from each teachers' background, (4) interpreted the teachers' responses from theories used in this study. The analysis was done after collecting the data by checking what the teacher answers, thoughts and actually done to get the participant directly to get their perception 
towards the reading strategies they taught. The analysis was used to make categories of reading strategies. As a result, the researchers were able to identify which strategy the teachers mostly taught during EFL classes.

\section{RESULTS AND DISCUSSION}

The findings and discussions are divided into two main parts. The first part presents kinds of reading strategies mostly taught by experienced EFL teachers. The second part presents about EFL teachers' perspective on each reading strategies. Table 1 shows that three groups of teachers use various strategies during the teaching of reading.

Table 1. Kinds of reading strategies mostly taught by EFL teachers

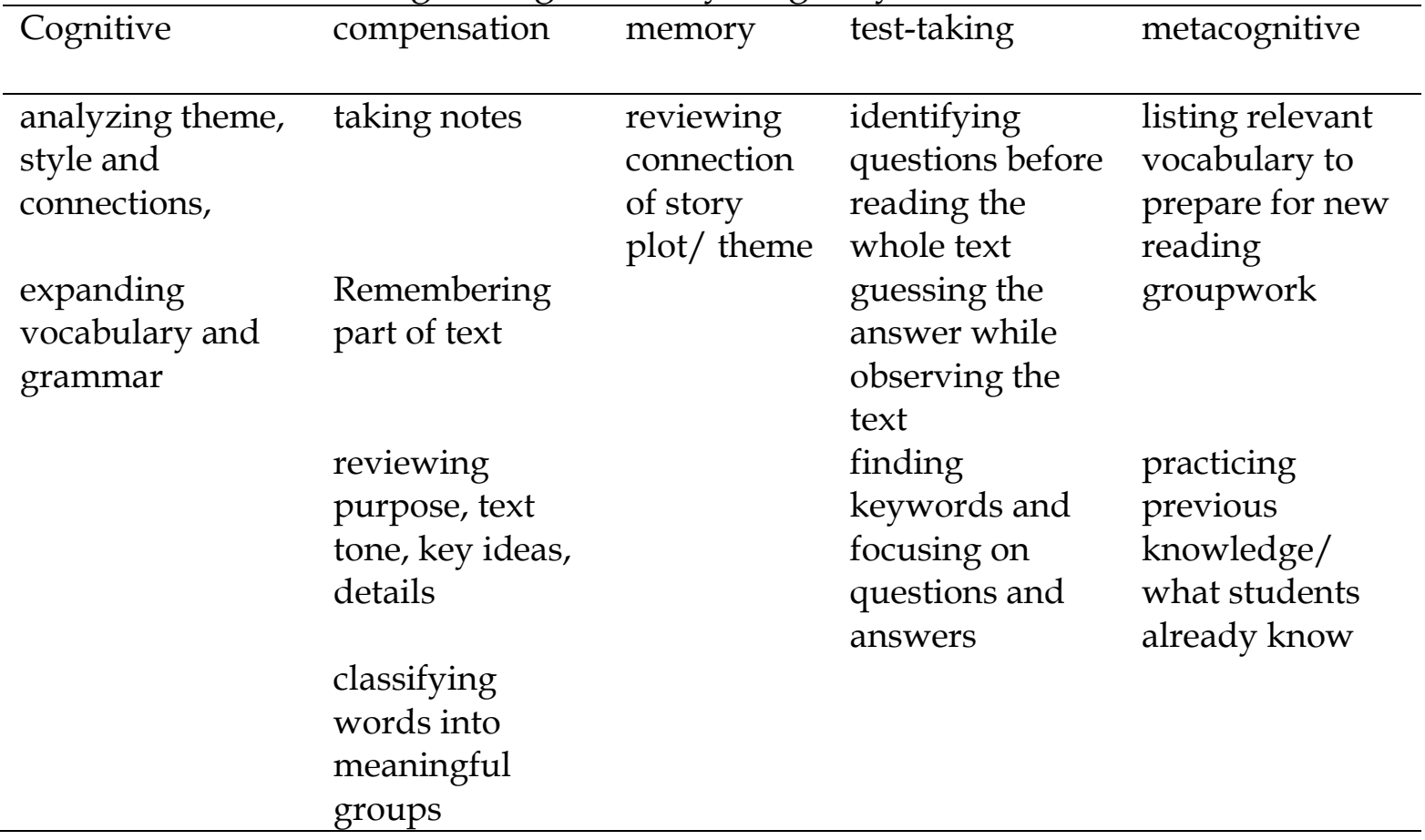

Table 2 shows the interview results describing teachers' perspectives: reading strategy can fasten their reading time and improving reading skill of students by mentioning some strategies such as finding main idea, understanding question individually, discussing the text types, understanding synonym and difficult words and making examples/ stories.

Table 2. The summary of the interview

\begin{tabular}{|c|c|c|c|c|}
\hline Teachers & $\begin{array}{l}\text { Students } \\
\text { problem }\end{array}$ & $\begin{array}{l}\text { Strategy taught to help } \\
\text { students understanding } \\
\text { passage }\end{array}$ & $\begin{array}{l}\text { What teachers } \\
\text { know about } \\
\text { kinds of reading } \\
\text { strategies }\end{array}$ & $\begin{array}{c}\text { Teachers } \\
\text { opinion about } \\
\text { the teaching of } \\
\text { RS to high } \\
\text { school students }\end{array}$ \\
\hline A & $\begin{array}{l}\text { Understanding } \\
\text { meaning, } \\
\text { vocabulary, } \\
\text { finding main } \\
\text { idea, taking } \\
\text { summary of } \\
\text { story }\end{array}$ & $\begin{array}{l}\text { Three phase } \\
\text { techniques, reading } \\
\text { each paragraph, } \\
\text { finding main idea, } \\
\text { understanding } \\
\text { question individually, } \\
\text { discussion, } \\
\text { understanding difficult } \\
\text { words in the question, }\end{array}$ & $\begin{array}{l}\text { It really helps } \\
\text { students by } \\
\text { opening } \\
\text { dictionary, } \\
\text { finding answer } \\
\text { while reading } \\
\text { the text\& } \\
\text { question, I don't } \\
\text { know the term }\end{array}$ & $\begin{array}{l}\text { It can help } \\
\text { students in } \\
\text { understanding } \\
\text { any situation of } \\
\text { text, } \\
\text { whenever\& } \\
\text { wherever they } \\
\text { are. It can add } \\
\text { students' }\end{array}$ \\
\hline
\end{tabular}




\begin{tabular}{|c|c|c|c|c|}
\hline Teachers & $\begin{array}{l}\text { Students } \\
\text { problem }\end{array}$ & $\begin{array}{l}\text { Strategy taught to help } \\
\text { students understanding } \\
\text { passage }\end{array}$ & $\begin{array}{l}\text { What teachers } \\
\text { know about } \\
\text { kinds of reading } \\
\text { strategies }\end{array}$ & $\begin{array}{c}\text { Teachers } \\
\text { opinion about } \\
\text { the teaching of } \\
\text { RS to high } \\
\text { school students }\end{array}$ \\
\hline & & $\begin{array}{l}\text { searching synonym, } \\
\text { giving example of } \\
\text { story, }\end{array}$ & $\begin{array}{l}\text { but incidentally I } \\
\text { have applied } \\
\text { them. }\end{array}$ & $\begin{array}{l}\text { vocabulary, can } \\
\text { add the speed } \\
\text { of reading in } \\
\text { exam \& } \\
\text { worksheet. It is } \\
\text { taught during } \\
\text { explaining the } \\
\text { content } \\
\text { material. }\end{array}$ \\
\hline B & vocabulary & $\begin{array}{l}\text { Vocab writing, giving } \\
\text { info on generic } \\
\text { structure, listing new } \\
\text { words and translate } \\
\text { By digging student self- } \\
\text { motivation \& } \\
\text { experience, giving } \\
\text { context of reading \& } \\
\text { Question, let the } \\
\text { students do task by } \\
\text { themselves }\end{array}$ & $\begin{array}{l}\text { It helps students } \\
\text { in answering } \\
\text { questions, I don't } \\
\text { know the term } \\
\text { test taking and } \\
\text { metacognitive } \\
\text { strategies }\end{array}$ & $\begin{array}{l}\text { It is good to } \\
\text { improve } \\
\text { students' } \\
\text { understanding } \\
\text { about narrative, } \\
\text { recount, } \\
\text { procedure, } \\
\text { descriptive text; } \\
\text { it doesn't affect } \\
\text { the stu speed in } \\
\text { understanding } \\
\text { the content. It is } \\
\text { really } \\
\text { important } \\
\text { because it can } \\
\text { give solution to } \\
\text { students }\end{array}$ \\
\hline $\mathrm{C}$ & vocabulary & $\begin{array}{l}\text { Giving words \& } \\
\text { meaning that needed, } \\
\text { modelling, Q\&A, CTL, } \\
\text { discussion, explanation } \\
\text { in front of the class. }\end{array}$ & $\begin{array}{l}\text { It can help the } \\
\text { students in } \\
\text { understanding } \\
\text { English text. } \\
\text { It is essential to } \\
\text { be taught to } \\
\text { improve reading } \\
\text { skill so the } \\
\text { students can } \\
\text { practice directly } \\
\text { whenever they } \\
\text { read }\end{array}$ & $\begin{array}{l}\text { It should be } \\
\text { taught during } \\
\text { the lesson } \\
\text { although } \\
\text { students are } \\
\text { lack of } \\
\text { anthusiasm }\end{array}$ \\
\hline $\mathrm{D}$ & $\begin{array}{l}\text { Understanding } \\
\text { vocabulary }\end{array}$ & $\begin{array}{l}\text { Giving words \& } \\
\text { meaning that needed, }\end{array}$ & $\begin{array}{l}\text { Just a little, } \\
\text { rarely teach } \\
\text { because student } \\
\text { work } \\
\text { individually in } \\
\text { their worksheets. } \\
\text { Almost all } \\
\text { students do not } \\
\text { have any }\end{array}$ & $\begin{array}{l}\text { It is good to } \\
\text { add student } \\
\text { experience and } \\
\text { fasten in } \\
\text { reading text }\end{array}$ \\
\hline
\end{tabular}




\begin{tabular}{|c|c|c|c|c|}
\hline Teachers & $\begin{array}{l}\text { Students } \\
\text { problem }\end{array}$ & $\begin{array}{c}\text { Strategy taught to help } \\
\text { students understanding } \\
\text { passage }\end{array}$ & $\begin{array}{l}\text { What teachers } \\
\text { know about } \\
\text { kinds of reading } \\
\text { strategies }\end{array}$ & $\begin{array}{c}\text { Teachers } \\
\text { opinion about } \\
\text { the teaching of } \\
\text { RS to high } \\
\text { school students }\end{array}$ \\
\hline & & & $\begin{array}{l}\text { difficulty in } \\
\text { reading / } \\
\text { understanding } \\
\text { text. }\end{array}$ & \\
\hline $\mathrm{E}$ & $\begin{array}{l}\text { Understanding } \\
\text { vocabulary } \\
\text { based on } \\
\text { context }\end{array}$ & $\begin{array}{l}\text { Giving example of } \\
\text { sentence, brain } \\
\text { storming, finding new } \\
\text { words }\end{array}$ & $\begin{array}{l}\text { Jigsaw, test } \\
\text { taking, I don't } \\
\text { know about } \\
\text { cognitive } \\
\text { strategy. Stu } \\
\text { comprehend } \\
\text { text, teacher give } \\
\text { question related } \\
\text { to content, } \\
\text { surface question } \\
\text { until deep } \\
\text { problem, then } \\
\text { brainstorming/ } \\
\text { Q\& A. }\end{array}$ & $\begin{array}{l}\text { It helps } \\
\text { students and } \\
\text { student can } \\
\text { understand. It } \\
\text { is essential to } \\
\text { enable students } \\
\text { in } \\
\text { comprehension, } \\
\text { introduce } \\
\text { teaching } \\
\text { variation to } \\
\text { avoid boredom, } \\
\text { and improve } \\
\text { the score. }\end{array}$ \\
\hline $\mathrm{F}$ & vocabulary & $\begin{array}{l}\text { Before lesson, students } \\
\text { were given } 10 \text { minutes } \\
\text { to read a passage }\end{array}$ & $\begin{array}{l}\text { Reading text } \\
\text { with pictures }\end{array}$ & $\begin{array}{l}\text { Introduce } \\
\text { songs, } \\
\text { homonym, } \\
\text { homophone } \\
\text { practice. }\end{array}$ \\
\hline
\end{tabular}

Other teachers said that the teaching of reading strategy can be a solution to help students elevating their comprehension about text types. Those teachers taught the reading strategies by building motivation, digging students' experience, giving the context of passage and asking guided questions from easy to difficult level. According to those EFL teachers, the teaching of reading strategies can avoid boredom in the reading class.

Table 3. Teachers' perception on reading strategies

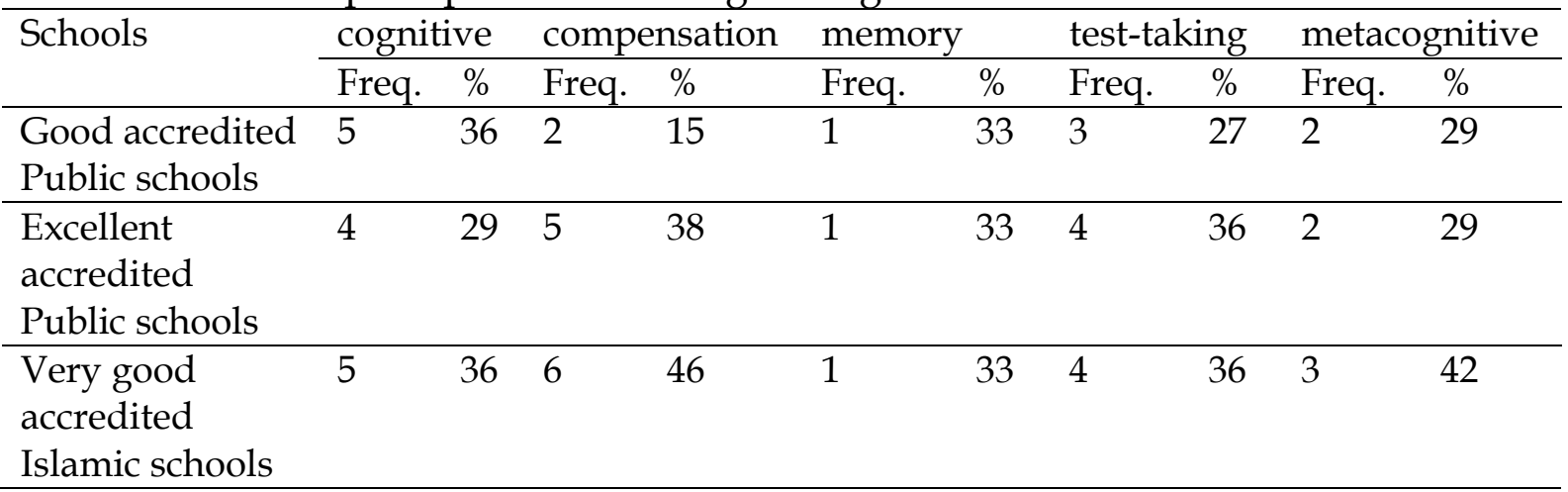

\section{Reading strategies mostly taught by experienced EFL teachers}

The study has found that teachers have mentioned numbers of reading strategies during the teaching of reading class. Table 3 shows that teachers from the three types of schools used relatively similar reading strategies to their students. EFL teachers in good accredited public schools employed five cognitive strategies (36\%), two 
compensation strategies $(15 \%)$, one memory strategy $(33 \%)$, three test-taking strategies $(27 \%)$ and two metacognitive strategies $(29 \%)$ during their teaching. Then, EFL teachers in excellent accredited public schools employed four cognitive strategies $(29 \%)$, five compensation strategies $(38 \%)$, one memory strategy (33\%), four testtaking strategies (36\%) and two metacognitive strategies (29\%) during their teaching. Next, EFL teacher in very good Islamic accredited public schools employed five cognitive strategies (36\%), six compensation strategies $(46 \%)$, one memory strategy $(33 \%)$, four test-taking strategies (36\%) and three metacognitive strategies $(42 \%)$ during the teaching.

\section{EFL teachers' perspective on each reading strategies}

This section presents the teacher's perspective on the rationale for selecting particular reading strategies in the classroom. This study has found some factors that incorporate teachers' perception on particular reading strategies such as reading strategies based on students' problems, reading strategies to help the student understand the reading passages, teachers' understanding about types of reading strategies, teachers' opinions about their teaching reading techniques, and teachers' beliefs,

\section{Reading Strategies based on students' problems}

From the interview with those EFL teachers, in a reading session, students face some problems such as understanding vocabulary, poor mastery of grammar, the difficulty in understanding long sentences, lack of media learning, less support from the family, lack of knowledge of strategies in reading comprehension. When reading, keeping attention from any reading distraction is quite hard and need efforts.

Besides that, the material development printed in books and given by teachers was quite difficult to absorb. The problem that it was above the average comprehension of most students in high school level. Because of less enjoyable learning in basic elementary study, students show their less motivation in reading and literacy. Their common difficulties are understanding meaning and vocabulary based on context, finding main idea and summarizing. They need to read something that is familiar for them. In conclusion, the main students' problem based on the interview results are understanding meaning, remembering vocabulary, finding main idea and summarizing passage.

\section{Reading Strategies to help the student understand the reading passages}

However, those EFL high school teachers tried to help their students understanding the reading passages in each meeting consistently by applying these kinds of strategies to help their students during the reading session such as: monitoring students' comprehension and vocabulary, improving metacognitive strategies, answering and generating questions, recognizing story structure and summarizing the story/ passage.

In spite of that, teacher can ask their students to follow simple strategies that can be used to work on the comprehension skills such as improving vocabulary by some techniques, coming up with questions about the text you are reading, using context clues, looking for the main idea, writing a summary of what you read, breaking up the reading into smaller sections, re-reading text to ensure understanding while looking up the meaning, and reading aloud. 
From the interview results, teacher A employs some strategies such as three phase techniques, reading each paragraph, finding main idea, understanding question individually, discussion, understanding difficult words in the question, searching synonym, giving example of story. Teacher B employs some strategies such as vocabulary writing, giving info on generic structure, listing new words and translate, digging students' self-motivation and experience, giving context of reading and question, let the student to do task by themselves. Teacher C employs some strategies such as giving words \& meaning that needed, modelling, Questions \& Answers (Q\&A), Contextual Teaching and Learning (CTL), discussion, and explanation in front of the class. Teacher D employs some strategies such as giving words \& meaning that needed. Teacher E employs some strategies such as giving example of sentence, brain storming, and finding new words. Teacher F employs some strategies such as giving time to free reading session ten minutes before the lesson started to read a passage.

\section{Teachers' understanding about types of reading strategies}

From the interview and questionnaire results, teacher A with more than 10 years teaching experience said that reading strategies can really help students. They were practicing some strategies such as opening dictionary, finding answer while reading text, answering directly while reading the question. She did not know the term or types of reading strategies included during the practice but she incidentally applied it one after another. Teacher B with more than 6 years teaching experience said that she helped students in answering questions, but she does not know the term of test taking strategies and metacognitive strategies. Teacher $C$ with more than 15 years teaching experience said that she helped the students in understanding English text and improving reading skill so the students can practice directly whenever they read. Teacher D with more than 1 year teaching experience said that she rarely taught that kind of reading strategies because students worked individually in their worksheets. Almost all students do not have any difficulty in reading / understanding text. Teacher E with more than 22 years teaching experience said that she applied jigsaw and some test taking strategies. She does not know about cognitive strategy. She realized that after students comprehended a text, the teacher should give questions related to content by some surface questions and deep analytical questions then were followed by brainstorming or Question and Answer. Teacher F with more than 11 years teaching experience said that she applied the strategy of reading some texts by combining it with related pictures.

\section{Teachers' opinions about their teaching reading techniques}

Dja'far (2016) says the perception of student motivation questionnaire and an achievement test were utilized to assess students' motivation and ESP learning achievement, respectively. The students' scores provided by the teachers were used as the basis of students' motivation level to show their high, moderate, and low motivation.

Research shows that students who encounter learning difficulties in reading and writing due to some inabilities can, however, learn reading and writing, though at a slower pace than an average student. Nonetheless, it is pointed out that these students will require more time, attention and resources (National Joint Committee on Learning Disabilities [NJCLD], 1993) in Ates and Yildirim (2010). 
From the interview and questionnaire results, teacher A stated that some reading strategies learnt can help students in understanding any situation of the text, whenever\& wherever they are. It can give benefit to students' vocabulary, the speed of reading during the exam \& worksheet. Further, she said that it was better that teacher taught intensively during explaining the content material. Teacher B said that additional reading strategies were good to improve students' understanding in comprehending narrative, recount, procedure and descriptive texts although they do not affect the students' speed in understanding the content. She assumed that reading strategies were really important because they could give solution to students' problem. Teacher $\mathrm{C}$ stated that those reading strategies should be taught during the lesson although students sometimes are lack of anthusiasm. Teacher D stated that learning reading strategies were good to add students' experience so their reading skill could be fastened. Teacher E stated that reading strategies help students to understand. It was essential to enable students' comprehension toward different passages by introducing teaching variation and method to avoid boredom that beneficial in improving the students' minimum score. Teacher F stated that she practiced some beneficial reading strategies by introducing songs, homonym and homophone practice.

\section{EFL teachers' beliefs}

The analysis of the teachers' professional performance cannot ignore their perceptions, attitudes and job satisfactions (Corina, 2012). Spor and Schneider (2005) said a major task facing today's classroom teacher is identifying students who have reading difficulties, articulate their needs and then implement an appropriate, efficient and realistic plan for improvement. The analysis of the teachers' professional performance cannot ignore their perceptions, attitudes and job satisfactions (Corina, 2012). Spor and Schneider (2005) said a major task facing today's classroom teacher is identifying students who have reading difficulties, articulate their needs and then implement an appropriate, efficient and realistic plan for improvement. The result of the qualitative analysis to the data collected are interpreted to shape the students' problems, reading strategy mostly taught, teachers' opinion and knowledge. To enrich the data, however, the researcher tries to elaborate the terms known by teachers to get valid data and examples of strategy introduced to their students during the reading class. Such terms are being used as significant activity as they have difficulties in explaining the reading strategy used/ taught and kinds of method or instruction in teaching.

Technically, brief responses are showed up to avoid misinterpretation as those EFL teachers do not know the term of each reading strategies being taught. They just teach based on most problem found in EFL reading class that is vocabulary. They showed their best effort that they can do in improving the students' reading skill, building enjoyable environment, giving as many as exposure during reading activity and introducing the way how to do them. The actions of activating, inferring, monitoring-clarifying, questioning, searching-selecting, summarizing, and visualizing-organizing some new knowledges in the area of contextual reading passage which are coming from intense interaction can build the students awareness into comprehension. To reach the core message and critical point in reading, they use those collaborative reading strategies to understand what they read before, during and after reading. 
Observations were conducted to get positive insight about the teachers' efforts in reading strategies they adapt. In fieldnotes, most of EFL teachers believed that continue practice makes perfect. Three phase technique as pre, whilst and post strategy as usual direct instructions such as opening dictionary, viewing the task questions, writing vocabulary list, giving motivation, practicing enjoyable reading activity. In addition, jigsaw, peer work and simple games can avoid boredom are considered useful learning strategy in increasing reading experience.

The compensation approach seems to be more popular in two schools (excellent accredited public school and very good-accredited Islamic schools) than goodaccredited schools. Compensation strategies are strategies that students are learning in the reading class by taking notes, remember part of text, reviewing purpose, text tone, key ideas, details and classifying words into meaningful groups. Some researchers, Ismail, et.al. (2015), Gelbar, et.al. (2018), Viersen, et.al. (2019), have found that compensation strategies is effective to promote students' motivation and the improvement of reading skills. Ismail et.al. (2015) have mentioned that the compensatory strategies such as smart reading is found to be positively correlated with the learners' motivation to read and their belief about own reading competence. They suggest that low-achiever learners would most benefit from the recognition of compensation as a legitimate skill of reading comprehension. Meanwhile, Viersen et.al. (2019) state that compensation is a plausible explanation for resolving literacy difficulties in gifted students.

However, the next question is whether relying solely on this type of reading strategy approach is feasible enough to guarantee effective reading class? Experienced teachers in junior high schools still have challenges to struggle and consider what is the most suitable one to solve their students' problems and elaborate reading instruction in the classroom. To become successful independent learners, striving readers must develop a repertoire of reading strategies that can be selectively activated by the learner to meet the particular demands of differing text materials and assignments (Nam\& Leavell, 2011). EFL teachers can equip learners by inserting skills which are needed during the process of learning. The students need to be trained to use the strategies, while integrating the reading strategy instruction into the school curriculum. It seems that EFL teachers merely often ask their students to read, answer, share with peers/ group without teaching what they need. It is like giving the students a bunch of fishes without knowing how they should do fishing on the other day.

It will be more useful to prepare the hooks than only the fishes so that students can search fishes by themselves in future. Teachers were exposed to a wide range of cognitive strategies and curricular approaches to strategy use. Since few studies have followed teachers and classrooms beyond the completion of interventions, little is known about the persistence of strategy use and instruction over time (Young in Vasquez, 2010). According to them, their teaching techniques, styles or methods were suitable for their students since they were the influential teacher in the schools and they knew their students well. It can broaden EFL teachers' perspectives of this particular phenomenon of applying reading strategies. Such description on each reading strategies are arranged well such as cognitive strategies, compensation strategies, memory strategies, test-taking strategies and metacognitive strategies. 


\section{CONCLUSION}

This study has found that teachers' perceptions of the teaching of reading strategies are closely related to the teachers' readiness of sharing the knowledge about reading strategies based on students' problem and teachers' belief of language proficiency. When teachers have sufficient knowledge of reading strategies, they will find it easier to teach these strategies to their students. As a result, their students are able to complete reading tasks quite well. This study found that compensation, testtaking and metacognitive strategies are among mostly taught strategies in the reading class. Yet, this study has found that the teachers admittedly do not teach all reading strategies to their students. These teachers believe that their students with the reading strategies they have mastered so far are able to complete tasks.

EFL teachers teaching at junior high school level in good accredited public schools have taught almost all reading strategies. Meanwhile, EFL teachers from excellent accredited public schools only practiced several types of reading strategies. This is because most of their students have mastered the reading strategy well as evidenced by their excellent student learning outcomes. Teachers in excellent accredited public schools do not interfere much with the learning strategies of their students. Furthermore, teachers in private Islamic school rarely practice numbers of reading strategies. Yet, their students enjoy practicing reading activities practicing based on the teachers' instruction.

Mastering reading strategies is essential, however, other factors also such as the level of language proficiency of students need to be considered to explain the reading difficulties that students face in the reading class. Another issue such as the ideal ratio between the number of students and teachers is often a factor that we consider in creating an ideal reading class.

\section{RECOMMENDATION}

EFL teachers need to keep their professional development improved continuously. They should make themselves updated with current studies of ELT/EFL and latest application of technology. Teachers' perception on reading strategies are put into consideration by future researchers in order to expand the body of knowledge on the teaching of reading as well as to offer solutions to the problems faced by EFL teachers in Indonesian high schools in the classrooms problem.

\section{ACKNOWLEDGMENT}

This research received no specific grant from any funding agency in the public, commercial, or not for profit sectors.

\section{REFERENCES}

Ali \& Razali. (2019). A review of studies on cognitive and metacognitive reading strategies in teaching reading comprehension for ESL/EFL Learners. English Language Teaching, 12 (6), 1916-4742

Ates \& Yildirim (2010). Opinions of classroom teachers and prospective classroom teachers about the learning difficulties encountered in the teaching process of reading and writing, Elementary Education Online, 9(1), 44-51, 2010

Brevik, L. (2019). Explicit rStrategy instruction or daily use of strategies? Studying the teaching of reading comprehension through naturalistic classroom observation in English L2. Read Writ, 32(1), 2281-2310 
Emaliana. (2008). Using the jigsaw technique to increase the motivation of the XIth of SMA negeri 12 Malang in narrative texts. Unpublished Thesis. Malang: State University of Malang

Cahyono \& Widiati. (2006). The teaching of EFL reading in the Indonesian context: the state of the art. Teflin Journal, 17 (1), 36-58

Corina, V. (2012). Teachers' perceptions and attitudes towards Professional activity. Procedia - Social and Behavioral Sciences 51(1), 167-171 https://doi.org/10.1016/j.sbspro.2012.08.139

Diniah. (2013). Teachers' perceptions towards the use of English textbook in EFL classrooms (A descriptive study Of EFL teachers at one Islamic senior high school in Cirebon). Journal of English And Education, 1(2), 72-81

Dja'far, V., H. (2016). EFL teachers' perception of university students' motivation and ESP learning achievement. Journal of Education and Practice 7(14). 1-15

Dogan, C., \& Tosun, B. (2019). Critical reading in EFL courses: the facile and challenge confronted. International Online Journal of Education and Teaching, 6(3), 500-509.

Djiwandono, P.I. 1994. EFL Reading Strategies of Indonesian Learners. Unpublished Thesis Malang : Jurusan Pend. Bahasa Inggris, PPS IKIP Malang.

Dubin, F., \& Bycina, D. (1991). Academic reading and the ESL/EFL Teacher. In M.

Celce-Murcia (Ed.), Teaching English as a Second or Foreign Language (2nd ed., pp. 195215). New York: Newbury House

Fitri, D., I. (2011). A study on reading strategies taught by the English teachers of SMPN 2

Kepanjen and SMPN 4 Kepanjen. Unpublished Thesis, Malang: State University of Malang

Gelbar, N. W., Bray, M., Kehle, T. J., Madaus, J. W., \& Makel, C. (2018). Exploring the nature of compensation strategies in individuals with dyslexia. Canadian Journal of School Psychology, 33(2), 110-124.

Ginting, D. \& Saukah, A. (2016). Tests of writing in the school examination in upper secondary schools. Sage Open. , 1-7doi:10.1177/2158244016673130

Herman, P., Perkins, K., Hansen, M., Gomez, L., \& Gomez, K. (2010). The effectiveness of reading comprehension strategies in high school science classrooms. ICLS volume 1. Chicago: USA; Proceedings of the $9^{\text {th }}$ International Conference of The Learning Sciences, June 29- July 2, 2010

Hidayati, D. (2018). Students difficulties in reading comprehension at the first grade of SMAN 1 Darussalam Aceh Besar. Unpublished Thesis. Faculty of Education and Teacher Training Ar-Raniry State Islamic University Darussalam- Banda Aceh

Hudson, T. (2007). Teaching second language reading. NY: Oxford University Press

Hudri \& Naim. (2019). An Analysis of teacher strategies in teaching reading at the first years students of SMK 2 Gerung in academic year 2016/2017. Linguistic and ELT Journal Muhammadiyah University of Mataram 5 (2).

Ismail, S. A., Petras, Y. E., Mohamed, A. R., \& Eng, L. S. (2015). Compensatory reading among ESL Learners: A Reading Strategy Heuristic. English Language Teaching, $8(8), 46-55$.

Mahmoud, E., Y. (2019). Teachers' perceptions of reading instructional strategies and reading assessment strategies used in private high schools. Unpublished Thesis. United Arab Emirates University 
Nam, K., H. Leavell, \& Alexandra. (2011). Reading strategy instruction, metacognitive awareness, and self-perception of striving college developmental readers. JCLL $37(1)$

Nugroho, T., Bharati, D., \& Hartono, R. (2019). English teachers' perception on strategies in teaching reading comprehension to motivate the students. English Education Journal. English Education Journal 9 (1) 56 - 61

Troike. (2012). Introducing second language acquisition. UK: Cambridge University Press

Van Viersen. S., de Bree, E. H., \& de Jong, P. F. (2019). Protective factors and compensation in resolving dyslexia. Scientific Studies of Reading, 23(6), 461-477

Vasquez, A., Hansen, A. L., \& Smith, P. C. (2010). Teaching language arts to English language learners. New York: Routledge

Zhang, Z. (1993). Literature review on reading strategy research. Paper Presented at The Annual Meeting of The Mid-South Educational Research Association New Orleans LA Nov 10-12, 1993 https:/ / pdfs.semanticscholar.org/ 